\title{
Tibor Z. Harmathy
}

\author{
Jack Watts, Glen Dale Farm, 1455 Cider Mill Road, Cornwall, VT 05753, \\ $U S A$ \\ John Gales*, Carleton University, 3432 Mackenzie, 1125 Colonel By Drive, \\ Ottawa, ON K1S 5B6, USA
}

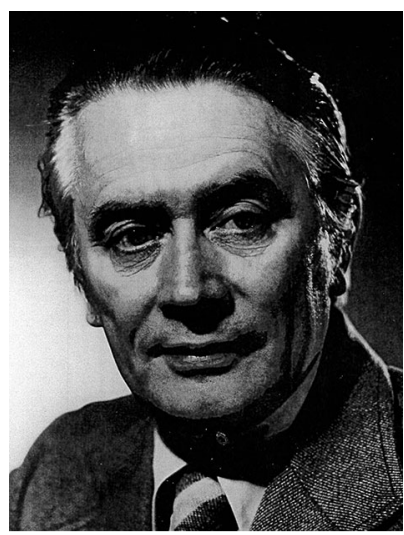

Tibor Z. Harmathy

Dr. Tibor Z. Harmathy was a pioneer and one of the founding fathers of contemporary fire safety engineering. In 1959, he joined the expanding Fire Research Section of the Division of Building Research (National Research Council of Canada-NRC) as a Research Officer. In his active career lasting nearly 30 years at the NRC, Tibor Harmathy authored well over 100 technical fire science related publications, several books, and numerous patents as well as editing many special publications, manuscript articles and conference proceedings.

Tibor was an active reviewer, contributor and editorial board member to our journal, Fire Technology. His contributions to the journal in its first year of publication include his 1965 classic, Ten Rules of Fire Endurance Rating [1], which is still used today by code officials for subjective evaluation of equivalency and performance designs. Over the next several decades Tibor had contributed well over a dozen articles to the journal Fire Technology including his well-regarded two part paper on, A New Look at Compartment Fires in 1972 [2, 3]. His last contribution

\footnotetext{
* Correspondence should be addressed to: John Gales, E-mail: john.gales@carleton.ca
} 
being Simplified Model of Smoke Dispersion in Buildings by Stack Effect published in 1998 [4].

Tibor was fundamental in promoting fire sciences internationally by presenting numerous papers at the conferences of various scientific and engineering societies: American Society of Testing and Materials (ASTM), the American Concrete Institute, and the Conseil International de Bâtiment (now CIB) for example. He was invited to several countries (Taiwan, China etc.) as part of scientific delegations to lecture about his experiences to help contribute to the establishment of fire research and services. Tibor was active on the ASTM E5 (now E05) Fire Standards committee as a chairman of the subcommittee on research. His activities included contributing and editing three special technical books [5-7]. His research activity and efforts were recognized in 1978, when Tibor was presented with the prestigious S.H. Ingberg award, and then again in 1986 with the Charles B. Dudley award. Tibor was recognized in 1989 with the Arthur B. Guise Medal awarded annually by the Society of Fire Protection Engineers (SFPE) in recognition of eminent achievement in the advancement of the science and technology of fire protection engineering. He was instrumental in organizing the 1st International Association for Fire Safety Science (IAFSS) symposium in California, US in 1986. He would eventually see the 4th symposium held in Ottawa, Canada in 1994.

At the Fire Research Section at NRC, Tibor was responsible for researching: the properties of building materials at elevated temperatures; the mechanisms of burning of compartment fires; and the fire resistance of building elements. Tibor's doctoral thesis, written when he began at the NRC, was titled: Simultaneous Moisture and Heat Transfer in Porous Systems with Particular Reference to Drying [8]. His thesis formed the basis of a well referenced paper and was finally transcribed for doctoral degree at the Vienna University of Technology in 1966 [9]. Tibor was active in developing patents at the NRC; of these included a building system that ensures that a fire remain confined to a single compartment (the compartment of origin) without the use of water (fire drainage) [10]. In 1979, Tibor succeeded Gordon Shorter as Section Head of the Fire Research Section at the NRC. In 1981, he oversaw the opening of the Fire Research Field Station (now the National Fire Laboratory of Canada) outside the city of Ottawa, Canada [11]. In its conception, the laboratory's primary objective was to provide researchers with the ability to test structures of realistic scale, geometry and fuel arrangement without the interference from adverse weather. In 1988, Tibor retired as Section Head, and after stepping down, he wrote the well-known book on Fire Safety Design \& Concrete [12]. That work was one of the first text books dedicated to structural fire engineering and an accumulation of his years of fire safety science experience. For several years afterwards, Tibor was active in consulting on various fire problems and technical publications. Active after retirement from the study of fire safety, Tibor regularly developed poetry writings, as well as authoring a fictional novel in 2009. 


\section{Acknowledgments}

Some details of this biography and photo were developed and collected respectively with assistance from the National Research Council of Canada. Dr. Agustin Majdalani, and Dr. Cristian Maluk are also thanked for providing comments towards this biography's development.

\section{References}

1. Harmathy TZ (1965) Ten rules of fire endurance rating. Fire Technol 1(2):93-102. doi:10.1007/BF02588479

2. Harmathy TZ (1972) A new look at compartment fires part 1. Fire Technol 8(3):196217. doi:10.1007/BF02590544

3. Harmathy TZ (1972) A new look at compartment fires part 2. Fire Technol 8(4):326351. doi:10.1007/BF02590537

4. Harmathy TZ (1998) Simplified model of smoke dispersion in buildings by stack effect. Fire Technol 34(1):6-17. doi:10.1023/A:1015352714123

5. Smith EEHarmathy TZ( (1979) Design of buildings for fire safety. American Society for Testing and Materials, STP 685, Philadelphia

6. Castino GHarmathy TZ( (1982) Fire risk assessment. America Society for Testing and Materials, STP, Philadelphia

7. Harmathy TZ( (1985) Fire safety science and engineering. America Society for Testing and Materials, STP 882, Philadelphia

8. Harmathy TZ (1966) Simultaner Feuchtigkeits- und Wärmetransport in porigen Systemen mit besonderem Hinweis auf Trocknung (in German). PhD thesis. Vienna University of Technology, 132pp

9. Harmathy TZ (1969) Simultaneous moisture and heat transfer in porous systems with particular reference to drying. I\&EC Fundam 8(1):92-103. doi:10.1021/i160029a016

10. Harmathy TZ, Oleszkiewicz I (1987) Fire drainage system. Fire Technol 23(1):26-43. doi:10.1007/BF01038364

11. Shorter G, Harmathy TZ (1983) Fire Research at the National Research Council of Canada: 1950 to 1979. Fire research at DBR/NRCC: proceedings of a symposium held in September 1981 to mark the opening of the DBR Fire Research Field Station. Ottawa, Canada, 119 pp

12. Harmathy TZ (1993) Fire safety design \& concrete. Longman Scientific and Technical, Harlow 